This is the peer reviewed version of the following article: J. Behnken, M. Yu, X. Deng, H. Tüysüz, C. Harms, A. Dyck, G. Wittstock, ChemElectroChem 2019, 6, 3460-3467 which has been published in final form at https://onlinelibrary.wiley.com/doi/10.1002/celc.201900722.

This article may be used for non-commercial purposes in accordance with Wiley Terms and Conditions for Use of Self-Archived Versions.

\title{
Oxygen Reduction Reaction Activity of Mesostructured Cobalt-based Metal Oxides Studied with Cavity-Microelectrode Technique
}

\author{
Julian Behnken, ${ }^{*[a, c]}$ Mingquan $Y u,{ }^{[b]}$ Xiaohui Deng,${ }^{[b]}$ Harun Tüysüz,${ }^{[b]}$ Corinna Harms, ${ }^{[a]}$ \\ Alexander Dyck ${ }^{[a]}$ and Gunther Wittstock ${ }^{*[c]}$
}

\begin{abstract}
Cobalt oxides are known as abundant and stable catalyst for the oxygen reduction reaction (ORR) in alkaline environment. Here, the ORR activity of $\mathrm{Co}_{3} \mathrm{O}_{4}$ and the mixed metal oxides $\mathrm{NiCO}_{2} \mathrm{O}_{4}$ and $\mathrm{CuCO}_{2} \mathrm{O}_{4}$ was studied. Synthesis by nanocasting procedure resulted in a mesostructured spinel phase with uniform morphology and high surface area. However, the evaluation of the specific activity of this material class is often hampered by limitations in determining the real surface area. The cavity-microelectrode technique did not require the addition of any additives to the catalytic material. Thus, measuring the double layer capacitance was used to assess the surface area. This approach showed comparable and reliable values for all samples and different cavity depths. Further, the in-situ derived surface area enabled the determination of the specific ORR activity, which is more accurate than utilizing the geometric and nitrogen absorption derived surface area. While the activity of $\mathrm{Co}_{3} \mathrm{O}_{4}$ was rather low, the presence of $\mathrm{Ni}^{2+}$ and $\mathrm{Cu}^{2+}$ in the mixed metal oxides led to a substantial activity enhancement possibly by providing additional active sites.
\end{abstract}

\section{Introduction}

Oxygen electrocatalysis is crucial to achieve a sustainable energy supply, where oxygen is evolved in electrolysers operated for converting electrical to chemical energy, and oxygen is consumed for the utilization of this energy by the reverse reaction in fuel cells. ${ }^{[1,2]}$ Current proton exchange membrane fuel cell technology relies on platinum group metals for the oxygen reduction redaction (ORR) due to the instability of transition metal oxides in contact with the highly developed acidic proton exchange membranes. Anion exchange membrane fuel cells have attracted increasing interest because they enable the use of abundant non-platinum group metal catalysts for the

[a] J. Behnken, Dr.-Ing. C. Harms, Dr. A. Dyck DLR Institute of Networked Energy Systems 26129 Oldenburg, Germany E-mail: julian.behnken@dlr.de

[b] M. Yu, Dr. X. Deng, Dr. H. Tüysüz Max-Planck-Institut für Kohlenforschung 45470 Mülheim an der Ruhr, Germany

[c] J. Behnken, Prof. G. Wittstock Institute of Chemistry, Carl von Ossietzky University 26129 Oldenburg, Germany

E-mail:wittstock@uol.de

Supporting information for this article is given via a link at the end of the document.
ORR at the cathode. ${ }^{[3]}$ The ideal cathode catalyst should combine high oxygen reduction activity close to that of platinumbased materials, high stability in alkaline environment under fuel cell operation conditions and high element abundance which goes along with low costs. Thus, perovskites ${ }^{[4-6]}$ as well as spinels ${ }^{[7-9]}$ based on abundant metals have attracted attentions as ORR electrocatalysts in alkaline electrolytes.

Among others, cobalt oxide-based spinels are intensively studied as electrocatalysts for the ORR. Their activity can be improved by addition of carbon supports ${ }^{[10]}$ and structural design of the catalyst morphology. ${ }^{[11]}$ In addition, the substitution of Co atoms by another transition metal leads to an enhanced oxygen reduction activity. ${ }^{[7,8,12,13]}$ Wei et al. ${ }^{[7]}$ demonstrated that this activity enhancement can be related to the metal cation in the octahedral site of the spinel lattice and its valence state. In their comprehensive study they showed an enhanced activity for spinels in the order $\mathrm{Co}_{3} \mathrm{O}_{4}<\mathrm{NiCo}_{2} \mathrm{O}_{4}<\mathrm{MnCo}_{2} \mathrm{O}_{4}$. Similarly, Sönmez et al. ${ }^{[8]}$ showed a superior activity of $\mathrm{NiCO}_{2} \mathrm{O}_{4}$ compared to that of $\mathrm{Co}_{3} \mathrm{O}_{4}$. Also $\mathrm{CuCo}_{2} \mathrm{O}_{4}$ as well as $\mathrm{Co}^{\prime \prime} \mathrm{Fe}^{\text {III }} \mathrm{Co}^{\prime \prime \prime} \mathrm{O}_{4}$ have been suggested as promising materials for the ORR. ${ }^{[12,13]}$

In principal, the ORR activity of these catalysts is studied with the rotating-(ring-)disk-electrode (RRDE or RDE) technique. ${ }^{[14-16]}$ A catalyst suspension is applied on the disk electrode, and after evaporation of the solvent, the resulting catalyst film can be studied under mass transport-controlled condition established by the rotation of the electrode. These thin films are composed of a polymeric binder (ionomer) and in some cases of an additional carbon support to increase the electrical conductivity. ${ }^{[7,15]}$ Guilminot and co-workers ${ }^{[17]}$ introduced the cavity-microelectrode (CME) technique as a versatile alternative for studying the ORR activity of powder materials. Due to the CME geometry a semi-hemispherical diffusion profile arises resulting in steady-state mass transport-limited currents in ORR polarization curve. Thereby, both setups possess similar masstransfer coefficients. ${ }^{[18]}$ CMEs have the advantage that the catalytic material can be studied without the need of adding any additive as required when preparing the composite thin film electrodes for RRDE measurements. Furthermore, only very low amounts (ng range) of the material are needed, ohmic and capacitive effects are negligible and fast scan rates can be applied. ${ }^{[17,19]}$ The comparability of polarization curves with CME and thin-film RDE was demonstrated for Pt-based materials in acidic electrolyte. ${ }^{[17]}$ Thus, the intrinsic activity of the catalytic material is probed using a CME in this study.

The resulting current is normalized for CME and RDE either by the electrochemical active surface area $\left(A_{E C S A}\right)$ giving the specific activity $S A\left[\mu \mathrm{Am}^{-2}\right]$, or if applicable by the mass of 
applied catalyst yielding the mass activity $\mathrm{MA}\left[\mathrm{A} \mathrm{g}^{-1}\right]$. Those quantities enable the comparison of different materials. For platinum-based catalyst, the charge of hydrogen underpotential deposition ( $\left.\mathrm{H}_{\mathrm{UPD}}\right)$, carbon monoxide stripping or of underpotential deposition of a metal is applied and referred to the known charge of a monolayer on a model surface to determine the $A_{E C S A}{ }^{[15,20]}$ However, the determination of the $A_{E C S A}$ is a widespread challenge for the evaluation of the ORR activity of metal oxides because no adsorption can be followed by voltammetry on metal oxides. ${ }^{[7,21]}$ Therefore, the current is usually normalized by the geometric surface area, e.g. the disk electrode area in RDE experiments, which does not account for the roughness or porosity of the sample. ${ }^{[1]}$ Other groups suggested the utilization of the particle size and the BET surface area calculated from $\mathrm{N}_{2}$-physisorption to assess the surface area. ${ }^{[1,7,16,22]}$ However, the ex-situ determined surface area of powders does not resemble the true surface area of the active sites contributing to the reaction. Other approaches quantify the surface area in-situ by measuring the double-layer capacitance in a suitable potential range, which is then compared to the specific capacitance of a flat surface of the same material in the same electrolyte. ${ }^{[1,23]}$ This strategy is a common approach for studying oxygen evolution catalysts. ${ }^{[23-25]}$ However, if the catalyst contains an additive like carbon in ORR studies the capacitance of the additive will influence the area assessment without contributing to the catalytically active surface area. $\left.{ }^{[7}, 16,26\right]$ Furthermore, the scan rate dependence of the charge of a voltammetric process can be utilized to determine the number of "inner and outer sites". ${ }^{27-29]}$ This procedure relies on the accessibility of surface sites which increases with decreasing the scan rate. By referring the charge to the geometric surface area of the electrode an approximation of the true area is possible. This method is useful only if the nature of the active site is known. ${ }^{[29]}$ Celorrio et al. ${ }^{[5,30]}$ suggested to refer the ORR activity to the number of manganese surface atoms of different $\mathrm{La}_{x} \mathrm{Ca}_{1-x} \mathrm{MnO}_{3}$ perovskites which were calculated by the integration of the cathodic response in cyclic voltammograms. This method is straightforward if the activity of a metal oxide can be linked to only one component and participation of redox centers in the bulk of the material can be excluded. So far, none of the described methods can be applied consistently to various catalyst compositions and experimental techniques complicating a comparison of the intrinsic ORR activity of metal oxide.

Here, metal oxide powders are supplied in cavitymicroelectrodes for the evaluation of their ORR activity. A commercial catalyst of platinum nanoparticles on a carbon support $(\mathrm{Pt} / \mathrm{C})$ was used as a reference material. The cobaltbased metal oxides are synthesized by a nanocasting procedure, where their composition is varied by the addition of another transition metal $(\mathrm{M}=\mathrm{Ni}, \mathrm{Cu})$. Therefore, high surface areas and large pore volumes can be achieved, making them highly valuable model systems for various reactions. $\left.{ }^{[25,} 31-34\right]$ The resulting spinel structure and surface composition are confirmed by X-ray diffraction (XRD), transmission electron microscopy (TEM) and X-ray photoelectron spectroscopy (XPS). Spinel type metal oxides possess a reasonable electronic conductivity ${ }^{[8,12,35}$, ${ }^{36]}$ and are studied without addition of carbon. Since no additives are added to the cavity during the electrochemical investigation, neither the employed double layer capacitance by cyclic voltammetry is affected by carbon ${ }^{[37]}$, nor the evaluation of the ORR activity is influenced by the addition of an ionomer. ${ }^{[17,38]}$ Thus, the intrinsic activity of the metal oxides can be extracted by referring the determined activity to the real surface area of the catalysts. Consequently, limitations in the evaluation of the specific ORR activity of metal oxides can be overcome.

\section{Results and Discussion}

Activity enhancement due to porosity and enlargement of the surface area has been intensively studied for mesostructured cobalt-based metal oxides applied as water oxidation catalyst. ${ }^{[25,}$ 34, 39-42] However, investigations for the ORR of these materials based on nanocasting are rare. ${ }^{[42]}$ The nanocasting procedure (Figure 1a) using the cubically ordered mesoporous silica KIT-6 as hard template resulted in mesostructured replicas (Figure 1b) of the metal oxides $\mathrm{Co}_{3} \mathrm{O}_{4}, \mathrm{NiCo}_{2} \mathrm{O}_{4}$ and $\mathrm{CuCo}_{2} \mathrm{O}_{4}$ in the spinel phase. Detailed structural characterization based on XRD, TEM, $\mathrm{N}_{2}$-physisorption and XPS measurements can be found in the supporting information. Briefly, all templated metal oxides have an ordered mesoporous structure with a surface areas and pore sizes of around $100 \mathrm{~m}^{2} \mathrm{~g}^{-1}$ and $4 \mathrm{~nm}$, respectively. The crystallite size of the particles is approximately $8 \mathrm{~nm}$ which fits well to the pore size of the silica template.

Electrochemical investigations of the metal oxides powders were performed by supplying them into CMEs. CMEs were prepared by potentiostatic electrochemical etching in hydrochloride solution of Au microelectrodes with a diameter of $50 \mu \mathrm{m}$ (Figure 1c). ${ }^{[43,44]}$ A smooth cavity bottom indicates a uniform etching process (Figure 1d) and the cavity depth $h$ was obtained from topographic reconstruction of a stack of confocal laser scanning microscopy (CLSM) images (Supporting Information, SI-2). The CMEs were filled by tapping into a small amount of the powder sample. Complete filling of the cavity was also controlled by CLSM images. Subsequently, the thickness of the catalyst layer is equal to the cavity depth (Figure 1e).

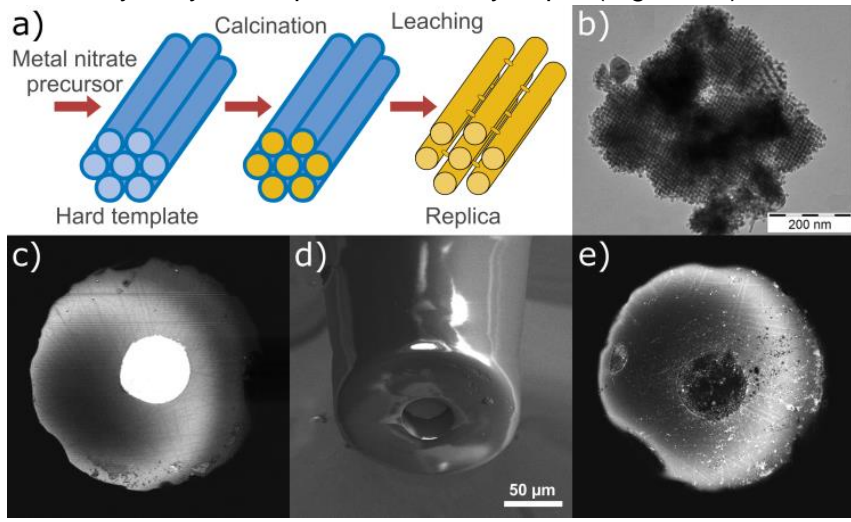

Figure 1. a) Nanocasting procedure and b) resulting mesostructured replica $\left(\mathrm{CuCo}_{2} \mathrm{O}_{4}\right)$. CLSM images of c) Au-microelectrode and e) CME filled with metal oxide $\left(\mathrm{Co}_{3} \mathrm{O}_{4}\right)$ as well as d) SEM image of an empty CME. 
The area of metal oxides samples $A_{\mathrm{MO}}$ in different CME was assessed by cycling the potential with various scan rates in a $\pm 50 \mathrm{mV}$ range around the open circuit potential (OCP). The calculated double layer capacitance $C_{\mathrm{DL}}$ was converted to a surface area which was then used to calculate a current density. This avoided the need to use the geometric surface area that cannot correct for different filling levels of the CME.

Exemplarily, the results for $\mathrm{CuCo}_{2} \mathrm{O}_{4}-\mathrm{CME}_{18 \mu m}$ are shown in Figure 2 and further measurements are presented in the supporting information (Figure S4 and Table S3). The double layer charging current $I_{c}$ increased with higher scan rates $v$ according to $I_{\mathrm{C}}=v C_{\mathrm{DL}}{ }^{[21,23]}$ Thus, $I_{\mathrm{c}}$ at OCP of anodic and cathodic scans was plotted against the applied scan rate to calculate the double layer capacitance by linear regression (Figure 2b). Only the linear part was considered since at higher scan rates uncompensated resistance can distort the current signal (Figure S4). An area of $0.017 \mathrm{~cm}^{2}$ was obtained for $\mathrm{CuCo}_{2} \mathrm{O}_{4}-\mathrm{CME}_{18 \mu \mathrm{m}}$ according to $A_{\mathrm{MO}}=C_{\mathrm{DL}} / C_{\mathrm{s}}$ with a specific capacitance $C_{\mathrm{s}}$ of $40 \mu \mathrm{F} \mathrm{cm}^{-2}$ for metal oxide in alkaline solution. ${ }^{[23]}$ Ideally, this $C_{\mathrm{s}}$ value has to be measured for a smooth, planar surface of each catalyst. This is hardly possible for nanostructured powdered metal oxides. Therefore, reported specific capacitances of metal electrodes were compared to approximate the value for metal oxides. ${ }^{[23]}$

A comparison of reported capacitance values for metal oxides showed that areas estimated based on this approximate value are better suited than geometric surface area or BET values. ${ }^{[2,24]}$ Therefore, the same specific capacitance value and procedure were used here for all studied metal oxides. The determined areas describe the surface area accessible to the electrolyte. ${ }^{[45]}$ For the other metal oxide samples similar values of $A_{\mathrm{MO}}$ between 0.012 and $0.034 \mathrm{~cm}^{2}$ were achieved. $A_{\mathrm{MO}}$ values of each catalyst investigated for the ORR in this study are listed in Table 1. Comparisons with other approaches are difficult, but an estimation using the BET surface area provides plausibility to the results. An area of $0.021 \mathrm{~cm}^{2}$ was calculated if a catalyst loading of $10 \%$ in the cavity is considered, and if employing the true density of $\mathrm{Co}_{3} \mathrm{O}_{4}$ of $6.11 \mathrm{~g} \mathrm{~cm}^{-3}$ as approximation (which should be very similar to $\mathrm{CuCo}_{2} \mathrm{O}_{4}$ ) and the BET surface area of $\mathrm{CuCo}_{2} \mathrm{O}_{4}$. The filling level of $10 \%$ is assessed by calculating the catalyst loading of $\mathrm{Pt} / \mathrm{C}-\mathrm{CME}_{21 \mu \mathrm{m}}$ as shown in the supporting information. This BET-derived area is slightly higher than the $A_{\mathrm{MO}}$ of $0.017 \mathrm{~cm}^{2}$ from the double-layer capacitance. A higher area using BET might originate from a different accessibility of the porous structure in the ex situ $\mathrm{N}_{2}$-physisorption measurements using a gas phase as adsorption agent and the in situ capacitance measurements using the charging/discharging of the electrochemical double layer in a liquid electrolyte. Smaller values by double layer capacitance compared to BET-derived values have also been reported before for other spinel type metal oxides based on RDE experiments. ${ }^{[24]}$

Besides the assessment of the surface area of metal oxides, the determination of the actual packing density of CMEs is challenging. Various procedure have been suggested which partially depend on the material under investigation. One possibility is the calibration of the cavity volume by the usage of
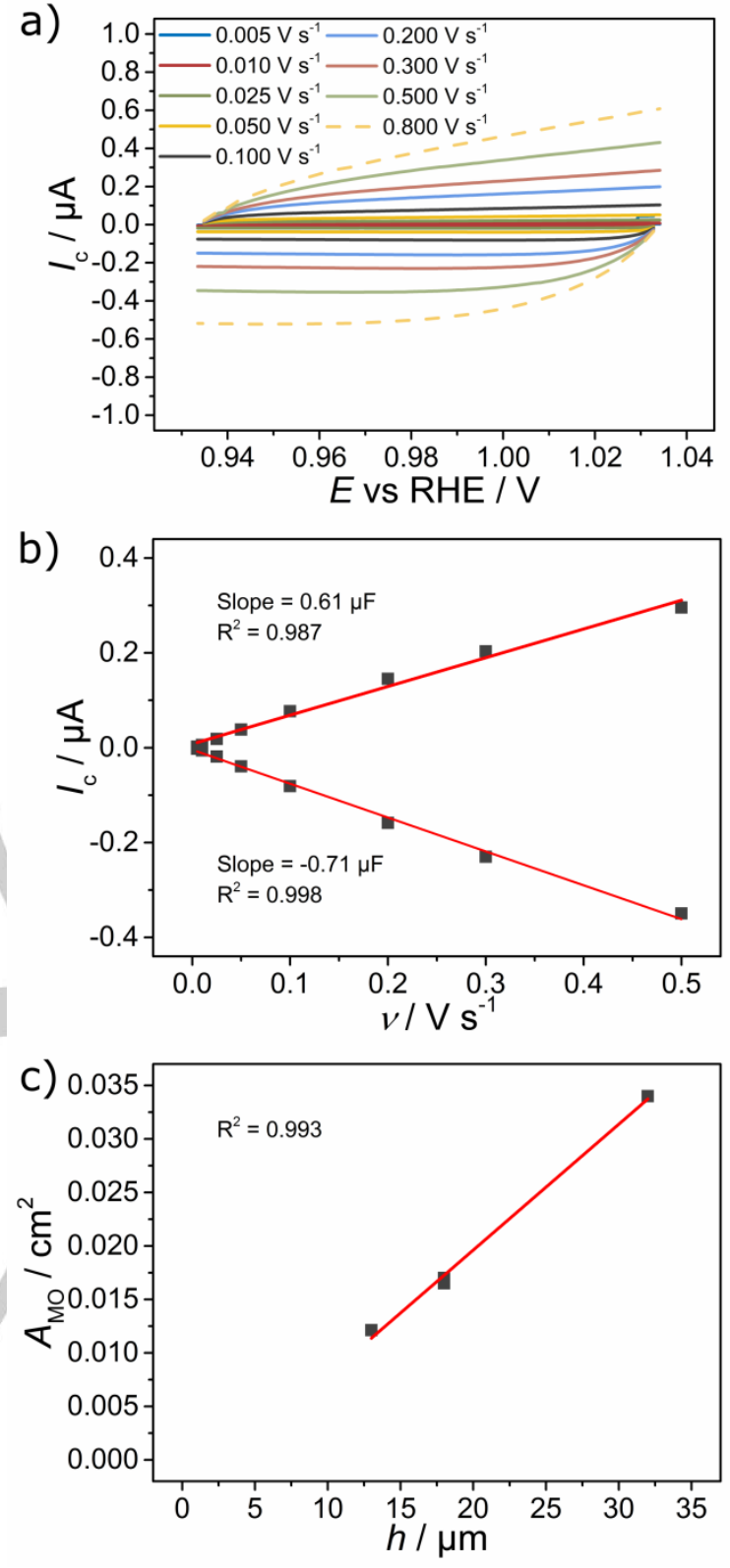

Figure 2. Assessment of the surface area of metal oxide $\left(\mathrm{CuCo}_{2} \mathrm{O}_{4}-\mathrm{CME}_{18 \mu \mathrm{m}}\right)$ catalyst by a) double layer capacitance measurements and b) linear regression of peak currents plotted against the scan rate. c) Area assessment for $\mathrm{CuCo}_{2} \mathrm{O}_{4}$ applied in $\mathrm{CME}$ with cavity depths of 11,18 and $32 \mu \mathrm{m}$ demonstrated uniform cavity loading. Dashed lines of a) are excluded from evaluation due to the influence of uncompensated resistance at higher scan rates.

a powder of known properties. ${ }^{[46]}$ This approach was also used by some of us to estimate the amount of material loaded into the cavity by measuring the charge of gold oxide reduction peaks or of $\mathrm{H}_{\text {UPD }}$ on carbon-supported Pt catalyst. ${ }^{[4]}$ In addition, the application of electrochemical impedance spectroscopy ${ }^{[43]}$ and the post-mortem dissolution of the studied material was suggested. ${ }^{[47]}$ Here, the linear increase of cavity depth and the amount of material loaded into the cavity is demonstrated for 
$\mathrm{CuCo}_{2} \mathrm{O}_{4}$ by determining the area of metal oxides for CME with various depths (Figure $2 \mathrm{c}$ ). Thus, an uniform cavity loading and accessibility can be expected. Moreover, the repeatability of emptying and filling of the cavity and the reproducibility of the surface area assessment was demonstrated for $\mathrm{CuCo}_{2} \mathrm{O}_{4-}$ $\mathrm{CME}_{18 \mu \mathrm{m}}$ (two points at $18 \mu \mathrm{m}$ depth in Figure 2c). Analogous linearity of $\mathrm{H}_{\mathrm{UPD}}$-derived $A_{\mathrm{ECSA}}$ and cavity depth was proven for the reference material $\mathrm{Pt} / \mathrm{C}$ (Figure S5b).

The determined $A_{M O}$ values were used to normalize the currents of $\mathrm{CV}$ measurements (Figure 3 ). The voltammogram of $\mathrm{Co}_{3} \mathrm{O}_{4}-\mathrm{CME}_{18 \mu \mathrm{m}}$ clearly showed in the positive-going scan the transition of $\mathrm{Co}^{2+/ 3+}$ starting at $1.2 \mathrm{~V}$ and $\mathrm{Co}^{3+/ 4+}$ around $1.4 \mathrm{~V}$ just before oxygen evolution begins at $1.55 \mathrm{~V} \cdot{ }^{[40,48]}$ In the negative scan, the corresponding reduction processes were visible at $1.42 \mathrm{~V}$ and around $1.3 \mathrm{~V}$. Redox processes of mixed metal oxides samples cannot be clearly assigned. Since XRD (Figure S1) and XPS (Figure S2) data indicated presence of $\mathrm{Co}^{3+}$ and $\mathrm{Ni}^{2+}$ as well as $\mathrm{Cu}^{2+}$ their transition states should also appear at similar potentials. However, for $\mathrm{NiCO}_{2} \mathrm{O}_{4}$ the transition of $\mathrm{Co}^{3+/ 4+}$ was diminished, which had also been reported in literature. ${ }^{[0,41]}$ The transition of $\mathrm{Ni}^{2+/ 3+}$ would appear at around $1.4 \mathrm{~V}$, but was not clearly visible for the $\mathrm{NiCO}_{2} \mathrm{O}_{4}-\mathrm{CME}_{30 \mu m}$ sample. ${ }^{[40]}$ The negative-going scan revealed one broad peak at around $1.25 \mathrm{~V}$ indicating slower electron transfer kinetics during the reduction. ${ }^{[49]}$ The $\mathrm{CuCo}_{2} \mathrm{O}_{4}-\mathrm{CME}_{18 \mu \mathrm{m}}$ sample showed one broad peak in the positive-going scan with a small feature at $1.42 \mathrm{~V}$ belonging to $\mathrm{Co}^{3+/ 4+}$ transitions. However, no additional peaks were present for a possible redox process of $\mathrm{Cu}$ ions. In the negative-going scan the voltammogram resembles features of $\mathrm{Co}_{3} \mathrm{O}_{4}$ indicating Co reduction.

The ORR activity of metal oxides was also studied by CME technique. Comparability of this technique with the RRDE technique was demonstrated for a Pt-based catalyst powder in acidic electrolyte by evaluation of the $A_{E C S A}$ as well as by studying the ORR kinetics. ${ }^{[17]}$ The non-negligible effect of binder material in RRDE was depicted as the main difference. Further, poisoning of Pt-based catalyst by the addition of ionomer is avoided. ${ }^{[38]}$ The ORR kinetics were evaluated by applying the classical Koutecky-Levich equation (Eq. 1) ${ }^{[15,18]}$

$$
I_{\text {kin,exp }}=\frac{I \cdot I_{\text {lim }}}{I_{\lim }-I}
$$

where $l_{\text {kin }}$ is the kinetically-limited current and $l_{\text {lim }}$ the diffusionlimited current. The macro-homogenous model by Gloaguen et al. ${ }^{[17,50-52]}$ (Eq. 2 and 3) was applied for the correction of oxygen diffusion through the active layer, which is necessary for film thicker than $3 \mu \mathrm{m} .{ }^{[53]}$

$$
\begin{gathered}
I_{\text {kin,exp }}=\frac{n F D_{\mathrm{O}_{2}} C_{\mathrm{O}_{2}}}{h} \cdot \sqrt{U_{h} I_{\text {kin,corr }}} \cdot \tanh \left(\sqrt{U_{h} I_{\text {kin,corr }}}\right) \\
U_{h}=\frac{h}{\left(n F D C_{0}\right)}
\end{gathered}
$$

where $l_{\text {kin,corr }}$ is the kinetic current corrected for oxygen diffusion in the solution and in the active layer, which is described by the factor $U_{h}, h$ is the active layer depth (here equal to the cavity depth), $n=4$ is the number of electron transferred in the reaction, $F=96,485 \mathrm{C} \mathrm{mol}^{-1}$ is the Faraday constant, $D_{\mathrm{O}_{2}}=1.93 \times 10^{-9} \mathrm{~m}^{2} \mathrm{~s}^{-1}$ is the oxygen diffusion

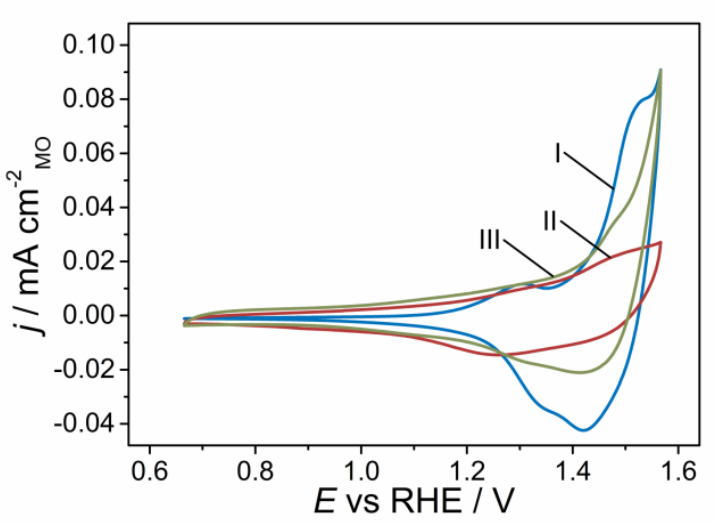

Figure 3. Cyclic voltammograms of $\mathrm{Co}_{3} \mathrm{O}_{4}-\mathrm{CME}_{18 \mu \mathrm{m}}$ (I, blue), $\mathrm{NiCo}_{2} \mathrm{O}_{4}$ $\mathrm{CME}_{30 \mu \mathrm{m}}$ (II, red) and $\mathrm{CuCO}_{2} \mathrm{O}_{4}-\mathrm{CME}_{18 \mu \mathrm{m}}$ (III, green) normalized by $A_{\mathrm{MO}}$.

coefficient and $C_{\mathrm{O}_{2}}=1.26 \times 10^{-3} \mathrm{~mol} \mathrm{~L}^{-1}$ is the oxygen solubility in potassium hydroxide solution. ${ }^{[54]}$ Eq. 2 was solved iteratively using a spreadsheet program. In a first approach, the CME technique was applied to a commercial $40 \mathrm{wt} \% \mathrm{Pt} / \mathrm{C}$ as reference material in $0.1 \mathrm{~mol} \mathrm{~L}^{-1}$ alkaline potassium hydroxide solution (Figure 4 and Figure S5). The resulting activities for $\mathrm{CME}$ with different depths at a potential of $0.90 \mathrm{~V}$ were $\mathrm{SA}=$ $(21.1 \pm 1.3) \mu \mathrm{A} \mathrm{cm}^{-2} \mathrm{Pt}$ and $\mathrm{MA}=(16.4 \pm 1.0) \mathrm{A} \mathrm{g}^{-1} \mathrm{Pt}$. Calculations are given in the supporting information. These values were similar to those of Guilminot et al. ${ }^{[17]}$ at $0.85 \mathrm{~V}$ but approximately one order of magnitude lower than values from RRDE studies at $0.90 \mathrm{~V}$ in alkaline electrolyte reported as $\mathrm{SA}=320 \mu \mathrm{A} \mathrm{cm}{ }_{\mathrm{Pt}}^{-2}$ and $\mathrm{MA}=150 \mathrm{~A} \mathrm{~g}^{-1} \mathrm{Pt}^{\left[{ }^{[7,16]}\right.}$ Deviations might occur due to the poorly controlled $\mathrm{O}_{2}$-mass transport in these measurements based on thick porous catalyst layers and packing of particles might reduce the surface area. ${ }^{[8,16]}$ The Tafel slopes $b$ of $\mathrm{Pt} / \mathrm{C}$ samples resulted in reasonable values of around $56 \mathrm{~b} / \mathrm{mV}$ at low current densities indicating a dissociative mechanism. Small deviations occurred for high current densities with values around $78 \mathrm{~b} / \mathrm{mV} .^{[16,55]}$ These results confirm the applicability of CME methodology for the evaluation of ORR kinetics in alkaline electrolyte. It was subsequently expanded to the analysis of metal oxide catalysts.

Reproducible ORR curves for various cavity depths were achieved although deviations were observed due to incomplete filling or packing of catalyst particles. These measurements were excluded from further evaluation (not shown). The measured currents were first normalized by the geometric area to enable comparison with $\mathrm{Pt} / \mathrm{C}-\mathrm{CME}$ (Figure S5c). However, kinetic data were referred to $A_{\mathrm{MO}}$ of the metal oxides $\left[\mu \mathrm{A} \mathrm{cm}^{-2} \mathrm{MO}\right.$ ] to enable comparison of different filling levels of the CME. Further, the polarization curve of $\mathrm{Pt} / \mathrm{C}-\mathrm{CME}_{21 \mu \mathrm{m}}$ was also plotted in Figure 4 for comparison reasons. Sample $\mathrm{Co}_{3} \mathrm{O}_{4}-\mathrm{CME}_{18 \mu \mathrm{m}}$ showed an onset potential of around $0.78 \mathrm{~V}$ for the ORR and no diffusionlimited current was reached (Figure 4a). Thus, the current might not be solely controlled by mass transport, but also influenced by electron transfer steps, which might occur due to the poor activity. ${ }^{[8]}$ Possibly formed peroxide as intermediate cannot be detected with CME technique, however also in RRDE studies on 
thick electrodes the evaluation is hampered due to decomposition of peroxide in the catalyst layer. ${ }^{[8,16]}$ The ORR activity of $\mathrm{NiCo}_{2} \mathrm{O}_{4}-\mathrm{CME}_{30 \mu \mathrm{m}}$ was substantial higher with an onset potential of $0.89 \mathrm{~V}$. The current reached a plateau suggesting diffusion-limited conditions. A similar behavior was observed for the $\mathrm{CuCo}_{2} \mathrm{O}_{4}-\mathrm{CME}_{18 \mu \mathrm{m}}$ sample with an onset potential of $0.90 \mathrm{~V}$ and a limiting current of $-2.4 \mathrm{~mA} \mathrm{~cm}^{-2}$ geo. In case of $\mathrm{Pt} / \mathrm{C}$ catalyst the onset potential was determined as $1.02 \mathrm{~V}$ and diffusion limited currents of $-7.4 \mathrm{~mA} \mathrm{~cm}^{-2}$ geo was observed.

The Koutecky-Levich equation and the macro-homogenous model were applied to evaluate the ORR kinetics. Limiting current densities were calculated by averaging the values between $0.50 \mathrm{~V}$ and $0.36 \mathrm{~V}$ and $\mathrm{SA}$ values were obtained at $0.85 \mathrm{~V}$ as well as $0.80 \mathrm{~V}$ and at $0.90 \mathrm{~V}$ as well as $0.85 \mathrm{~V}$ for metal oxides and $\mathrm{Pt} / \mathrm{C}$ catalyst, respectively (Table 1). The number of transferred electrons was assumed as four and thus determined SA values resemble the lower threshold of activities. Exact evaluation of this number from diffusion-limited current considering mass-transfer coefficients is difficult because neither the boundary conditions of an inlaid disk-microelectrode nor of a recessed microelectrode (empty CME) is ensured. ${ }^{[18,56]}$
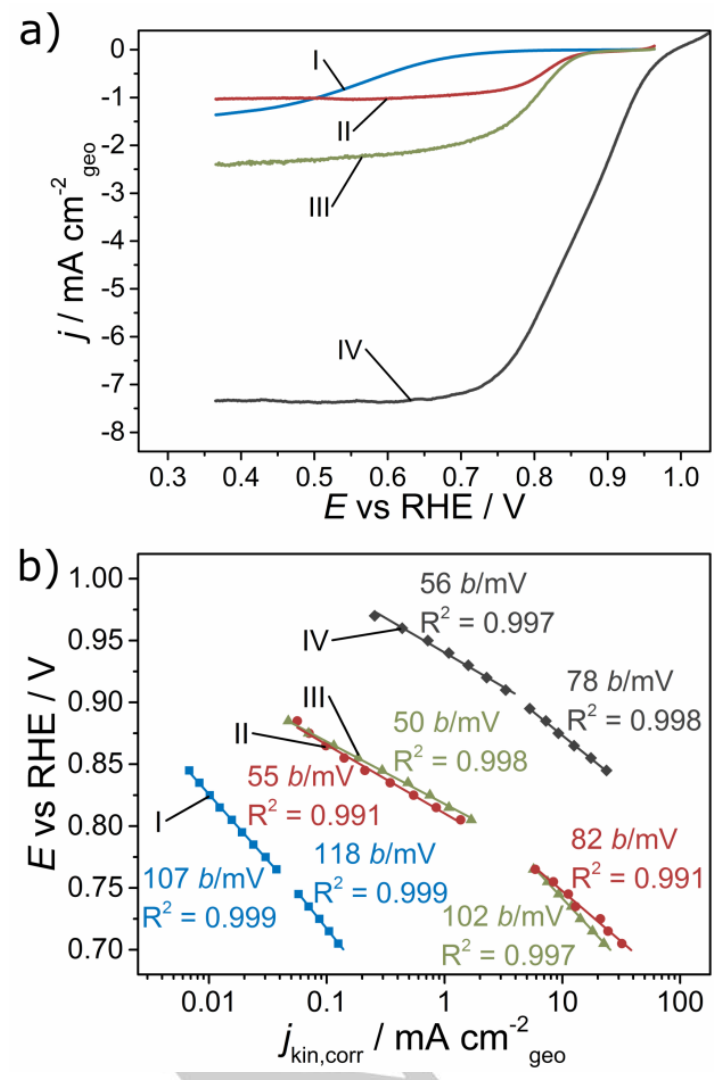

Figure 4. a) ORR polarization curves of $\mathrm{Co}_{3} \mathrm{O}_{4}-\mathrm{CME}_{18 \mu \mathrm{m}}$ (I, blue), $\mathrm{NiCo}_{2} \mathrm{O}_{4}$ $\mathrm{CME}_{30 \mu \mathrm{m}}$ (II, red), $\mathrm{CuCo}_{2} \mathrm{O}_{4}-\mathrm{CME}_{18 \mu \mathrm{m}}$ (III, green) and $\mathrm{Pt} / \mathrm{C}-\mathrm{CME}_{21 \mu \mathrm{m}}$ (IV, grey) in $0.1 \mathrm{~mol} \mathrm{~L}^{-1} \mathrm{KOH}$ solution with a scan rate of $1 \mathrm{mV} / \mathrm{s}$ for metal oxides and of $5 \mathrm{mV} / \mathrm{s}$ for $\mathrm{Pt} / \mathrm{C}$ catalyst and b) Tafel plot of respective ORR measurements, labelling of the data sets is the same as in a).
Table 1. Overview of specific activity values at various potentials.

\begin{tabular}{|c|c|c|c|c|c|c|}
\hline \multirow[t]{2}{*}{ Sample } & \multirow{2}{*}{$\begin{array}{l}A_{\mathrm{MO}} / A_{\mathrm{ECSA}} \\
/ \mathrm{cm}^{2}\end{array}$} & \multirow{2}{*}{$\begin{array}{l}\text { Onset } \\
\text { potential }^{\mathrm{c}} \\
\text { / V }\end{array}$} & \multirow{2}{*}{$\begin{array}{l}\mathrm{E} / \mathrm{V} \\
0.1 \mathrm{~mA}\end{array}$} & \multicolumn{3}{|c|}{$\mathrm{SA} / \mu \mathrm{A} \mathrm{cm}{ }^{-2} \mathrm{MO} / \mathrm{ECSA}$} \\
\hline & & & & $0.90 \mathrm{~V}$ & $0.85 \mathrm{~V}$ & $0.80 \mathrm{~V}$ \\
\hline $\begin{array}{l}\mathrm{Co}_{3} \mathrm{O}_{4^{-}} \\
\mathrm{CME}_{18 \mu \mathrm{m}}\end{array}$ & $0.014^{a}$ & 0.78 & 0 & - & 0.008 & 0.022 \\
\hline $\begin{array}{l}\mathrm{NiCo}_{2} \mathrm{O}_{4^{-}} \\
\mathrm{CME}_{30 \mu \mathrm{m}}\end{array}$ & $0.025^{\mathrm{a}}$ & 0.89 & 0.8 & 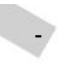 & 0.169 & 1.606 \\
\hline $\begin{array}{l}\mathrm{CuCo}_{2} \mathrm{O}_{4^{-}} \\
\mathrm{CME}_{18 \mu \mathrm{m}}\end{array}$ & $0.017^{a}$ & 0.90 & 0.87 & - & 0.312 & 2.507 \\
\hline $\begin{array}{l}\mathrm{Pt} / \mathrm{C}- \\
\mathrm{CME}_{21 \mu \mathrm{m}}\end{array}$ & $0.004^{b}$ & 1.02 & 0.98 & 20.11 & 89.20 & - \\
\hline
\end{tabular}

[a] $A_{\mathrm{MO}}$ assessed by capacitance measurements. [b] $A_{\mathrm{ECSA}}$ determined by charge of $\mathrm{H}_{\mathrm{UPD}}$. [c] Onset potentials derived by $1^{\text {st }}$ derivative of ORR curves.

Determination of MA of metal oxides was not possible because a gravimetric analysis of loaded catalyst is hardly possible. ${ }^{[19]}$ Assessment of the mass by utilizing the particle size ${ }^{[16]}$, as shown for $\mathrm{Pt} / \mathrm{C}$ samples in the supporting information, is challenging due to the morphology of metal oxide samples. $\mathrm{Co}_{3} \mathrm{O}_{4}-\mathrm{CME}_{18 \mu \mathrm{m}}$ showed a SA of $0.008 \mu \mathrm{A} \mathrm{cm}{ }^{-2} \mathrm{MO}$ at $0.85 \mathrm{~V}$ and $0.022 \mu \mathrm{A} \mathrm{cm}{ }^{-2}$ MO at $0.80 \mathrm{~V}$. Thus, $\mathrm{Co}_{3} \mathrm{O}_{4}$ possesses the poorest ORR activity in agreement with previous reports, while incorporation of another metal ion enhances the activity. ${ }^{[7,8]}$ Here, a consistent enhancement of the activity was observed for the $\mathrm{Ni}$ - and $\mathrm{Cu}$-containing spinel at $0.85 \mathrm{~V}$ with values of $0.169 \mu \mathrm{A} \mathrm{cm}^{-2}$ MO for $\mathrm{NiCo}_{2} \mathrm{O}_{4}$ and $0.312 \mu \mathrm{A} \mathrm{cm}^{-2}$ MO for $\mathrm{CuCo}_{2} \mathrm{O}_{4}$ sample. These values are around two orders of magnitudes lower than those of the reference sample $\mathrm{Pt} / \mathrm{C}-\mathrm{CME}_{21 \mu \mathrm{m}}$.

Calculated specific activities (Table 1) are hardly comparable with literature since $A_{\mathrm{MO}}$ values based on double layer capacitance measurements of metal oxides have not been performed for ORR catalyst. Instead Wei et al. ${ }^{[7]}$ reported SA values normalized by the BET area of around $8 \mu \mathrm{A} \mathrm{cm}^{-2}$ BET at $0.80 \mathrm{~V}$ for $\mathrm{Co}_{3} \mathrm{O}_{4}$ and $10 \mu \mathrm{A} \mathrm{cm}{ }_{\text {BET }}^{-2}$ at $0.85 \mathrm{~V}$ for $\mathrm{MnCo}_{2} \mathrm{O}_{4}$ (calcined at $500^{\circ} \mathrm{C}$ ). Assuming again a filling level of $10 \%$ in the cavity and considering the determined BET surface areas, in this study, SA values of around $0.24 \mu \mathrm{A} \mathrm{cm}{ }^{-2}{ }_{B E T}$ at $0.85 \mathrm{~V}$ were achieved for $\mathrm{CuCo}_{2} \mathrm{O}_{4}-\mathrm{CME}_{18 \mu \mathrm{m}}$. This deviation between the different methods might be related to mass transport limitation through the thick catalyst film and the packing of particles which might reduce the surface area in case of the CME technique. Further, Tafel plots were derived for metal oxides (Figure $4 \mathrm{~b}$ ). $\mathrm{NiCO}_{2} \mathrm{O}_{4}-\mathrm{CME}_{30 \mu \mathrm{m}}$ and $\mathrm{CuCo}_{2} \mathrm{O}_{4}-\mathrm{CME}_{18 \mu \mathrm{m}}$ possess Tafel slopes of $55 \mathrm{~b} / \mathrm{mV}$ and $50 \mathrm{~b} / \mathrm{mV}$ at low and $82 \mathrm{~b} / \mathrm{mV}$ and $102 \mathrm{~b} / \mathrm{mV}$ at high current densities in accordance to the $\mathrm{Pt} / \mathrm{C}$ reference material with values of $56 \mathrm{~b} / \mathrm{mV}$ and $78 \mathrm{~b} / \mathrm{mV}^{\left[{ }^{[16]}\right.}$ Deviations from the slopes for the $\mathrm{Co}_{3} \mathrm{O}_{4}-\mathrm{CME}_{18 \mu \mathrm{m}}$ sample suggest different reaction mechanism and lower activity. ${ }^{[1,16]}$

Another approach for activity evaluation is to compare the potential at which a specific geometric current density is reached, e.g. $-0.1 \mathrm{~mA} \mathrm{~cm}^{-2}{ }_{\text {geo. }}{ }^{[8]}$ This resulted in values of $0.71 \mathrm{~V}$ for $\mathrm{Co}_{3} \mathrm{O}_{4}-\mathrm{CME}_{18 \mu \mathrm{m}}$ and $0.86 \mathrm{~V}$ for $\mathrm{NiCo}_{2} \mathrm{O}_{4}-\mathrm{CME}_{30 \mu \mathrm{m}}$ matching well with previous data of Sönmez et al. ${ }^{[8]}$ for similar materials ( $0.72 \mathrm{~V}$ for $\mathrm{Co}_{3} \mathrm{O}_{4}$ and $0.81 \mathrm{~V}$ for $\mathrm{NiCo}_{2} \mathrm{O}_{4}$ ). Comparable values were also reported for $\mathrm{CuCo}_{2} \mathrm{O}_{4} \cdot{ }^{[12,26]}$ The reason for different 
activities might originate from the cations in the octahedral site of the spinel structure improving the overlap of the high-lying $e_{g}$ orbital and the oxygen $2 p$ orbital. ${ }^{[7]}$ These authors explained it by an optimized bonding strength of ORR reaction intermediates. Following this argumentation, $\mathrm{Co}^{3+}$ which occupies the octahedral position in the mixed-valence $\mathrm{Co}_{3} \mathrm{O}_{4}$ spinel has a low activity for the ORR. In another study, the activity was attributed to a surface enrichment of $\mathrm{Co}^{2+}{ }^{257]}$ This cannot be confirmed in this study as XPS results (Figure S2b and c) showed no main $\mathrm{Co}^{2+}$ contribution in the more active mixed metal oxides. In contrast, also surface-exposed $\mathrm{Co}^{3+}$ ions were described as active site for the ORR activity. ${ }^{[58]}$ In case of the mixed metal oxides $\mathrm{Ni}^{2+}$ and $\mathrm{Cu}^{2+}$ was observed in the XP spectra (Figure $\mathrm{S} 2 \mathrm{e}$ and f) which can also incorporate the octahedral site in the spinel lattice. ${ }^{[59,60]}$ This might be beneficial for the interaction with reaction intermediates and thus enhances the ORR activity. ${ }^{[7]}$ However, it is more likely that the divalent ions stay in the tetrahedral site and the increased activity is based on additional adsorption sites. ${ }^{[26]}$ Further, incorporation of $\mathrm{Ni}^{2+}$ and $\mathrm{Cu}^{2+}$ can increase the charge transfer rate, as shown recently by some of us. ${ }^{[25]}$ This will have a beneficial effect on the ORR activity. ${ }^{[9]}$

\section{Conclusions}

Mesostructured cobalt-based oxides $\mathrm{Co}_{3} \mathrm{O}_{4}, \mathrm{NiCo}_{2} \mathrm{O}_{4}$ and $\mathrm{CuCo}_{2} \mathrm{O}_{4}$ were synthesized and applied in cavitymicroelectrodes to study their oxygen reduction reaction activity in alkaline electrolytes. The nanocasting procedure resulted in a spinel structure with an uniform morphology and high surface areas of around $100 \mathrm{~m}^{2} \mathrm{~g}^{-1}$ making them highly valuable model system. The powders were applied in cavity-microelectrodes which did not require the addition of additives like an ionomeric binder or a carbon support to the catalytic material. These additives have either an influence on the double layer capacitance in the case of carbon or affect the ORR activity if an ionomer is added. Thus, the evaluation of the metal oxides surface area by measuring the double layer capacitance was not influenced by carbon and intrinsic properties were achievable. Areas between 0.013 and $0.034 \mathrm{~cm}^{2}$ were calculated reliably by this method. The uniform accessibility and loading of the cavities was further demonstrated by determining the surface area of metal oxides inserted into electrodes with various depths. Kinetic data of the oxygen reduction reaction were also not influenced by the ionomer and related to the determined surface area. Thus, the specific activity of metal oxides was achievable. While the activity of $\mathrm{Co}_{3} \mathrm{O}_{4}$ was rather low, the incorporation of $\mathrm{Ni}^{2+}$ and $\mathrm{Cu}^{2+}$ ions led to a substantial activity enhancement possibly due to additional active sites and an increased charge transfer rate. The highest activity was determined for the $\mathrm{CuCo}_{2} \mathrm{O}_{4}$ sample with a specific activity of $0.312 \mu \mathrm{A} \mathrm{cm}^{-2}$ мо at $0.85 \mathrm{~V}$. In general, the evaluation of specific activity values for metal oxides is hampered by uncertainties in the assessment of the surface area. Here, the presented approach should lead to an improved evaluation of the true ORR activity compared to the usage of the geometric surface area or the BET-derived surface area from ex-situ $\mathrm{N}_{2}$-physisorption in rotating-ring-disk-electrode studies. Therefore, the cavity-microelectrode technique can be used in future for a straightforward comparison of a wide variety of powder materials and facilitates the investigation of their intrinsic activities.

\section{Experimental Section}

\section{Materials}

Electrolytes were prepared using deionized water $(18 \mathrm{M} \Omega \mathrm{cm})$, potassium hydroxide powder (Merck, Germany), hydrochloric acid (Carl Roth, Germany) and sulphuric acid (Sigma Aldrich, Germany), respectively. Au microelectrodes were prepared from borosilicate glass capillaries (Hilgenberg, Germany) and gold wire (50 mm diameter, Goodfellow, Germany). As reference material $\mathrm{Pt} / \mathrm{C}$ catalyst was obtained from Johnson Matthey Fuel Cells (HiSPEC $\AA$ 4000, 40 wt\% Pt on Vulcan XC72R).

\section{Nanocasting of metal oxides}

The cobalt-based oxides $\mathrm{Co}_{3} \mathrm{O}_{4}, \mathrm{NiCo}_{2} \mathrm{O}_{4}$ and $\mathrm{CuCo}_{2} \mathrm{O}_{4}$ were synthesized by a nanocasting procedure described in detail elsewhere. ${ }^{[33}$ ${ }^{34,61]}$ In short, a cubically ordered mesoporous silica template that was aged at $100{ }^{\circ} \mathrm{C}$, KIT-6-100, was used as hard template. An ethanol solution of $0.8 \mathrm{~mol} \mathrm{~L}^{-1} \mathrm{Co}\left(\mathrm{NO}_{3}\right)_{2} \cdot 6 \mathrm{H}_{2} \mathrm{O}$ (Sigma Aldrich) was used as precursor solution for the synthesis of pure cobalt oxide. For the mixed metal oxides, solutions of the same total cation concentration were prepared, in which $\mathrm{Cu}\left(\mathrm{NO}_{3}\right)_{2} \cdot 3 \mathrm{H}_{2} \mathrm{O}$ (Sigma Aldrich) and $\mathrm{Ni}\left(\mathrm{NO}_{3}\right)_{2} \cdot 6 \mathrm{H}_{2} \mathrm{O}$ (Sigma Aldrich) were used to yield the desired metal ion ratio $\left[\mathrm{Co}^{2+}\right]:\left[\mathrm{M}^{2+}\right]$ of $2: 1(\mathrm{M}=\mathrm{Ni}, \mathrm{Cu})$. After impregnating the template with the prepared solutions and stirring for $1 \mathrm{~h}$ at room temperature, the mixture was dried at $60^{\circ} \mathrm{C}$ for $12 \mathrm{~h}$ and calcined at $200{ }^{\circ} \mathrm{C}$ for $4 \mathrm{~h}$ (ramping rate $2^{\circ} \mathrm{C} \mathrm{min}{ }^{-1}$ ). Afterwards, the impregnation was repeated and the mixture was dried and calcined at $500^{\circ} \mathrm{C}$ for $6 \mathrm{~h}$ with a plateau at $250^{\circ} \mathrm{C}$ for $4 \mathrm{~h}$ (ramping rate $2^{\circ} \mathrm{C} \mathrm{min}{ }^{-1}$ ). The silica template was removed in hot $2 \mathrm{~mol} \mathrm{~L}^{-1} \mathrm{NaOH}$ aqueous solution releasing a powdery black compound after centrifugation and drying.

\section{Structural characterization of metal oxides}

Wide angle XRD patterns collected at room temperature were recorded on a Stoe theta/theta diffractometer in Bragg-Brentano geometry $(\mathrm{Cu}$ $\mathrm{Ka}_{1 / 2}$ radiation). Small angle $\mathrm{X}$-ray scattering (SAXS) data were obtained with Anton Paar SAXSess (width of detection area: $3 \mathrm{~mm}$; exposure time: $1 \mathrm{~s}$; number of frames: 600). TEM images of samples were obtained with an $\mathrm{H}-7100$ electron microscope $(100 \mathrm{kV})$ from Hitachi. $\mathrm{N}_{2}$-physisorption isotherms were measured with an ASAP 2010 adsorption analyzer (Micrometrics) at $-196.15^{\circ} \mathrm{C}$. Prior to the measurements, the samples were degassed at $200^{\circ} \mathrm{C}$ for $20 \mathrm{~h}$. Total pore volume was determined using the adsorbed volume at a relative pressure of 0.97 . BrunauerEmmett-Teller-Method (BET) was used to determine surface areas from the relative pressure range between 0.06 and 0.2 . Pore size distribution curves were calculated by the Barrett-Joyner-Halenda-Method (BJH) from the desorption branch. The bulk composition of metal oxides was studied by mass spectrometry after atomization in an inductive coupled plasma (ICP-MS) using a XSeries2 instrument (Thermo Fisher). Approximately $2 \mathrm{mg}$ of metal oxide compounds were dissolved in concentrated nitric acid. Ruthenium was used as internal standard. XPS was performed using an ESCALAB $250 \mathrm{Xi}$ instrument (Thermo Fisher) with a non-monochromatized $\mathrm{Mg} \mathrm{K} \mathrm{K}_{\alpha}$ radiation $(h v=1253.6 \mathrm{eV})$. All 
samples were applied to a homemade powder sample holder made from aluminum. High resolution spectra were measured with pass energy of $10 \mathrm{eV}$. Peak deconvolution was performed with the software UNIFIT 2018 (Unifit Scientific Software $\mathrm{GmbH}$ ) using convolution of Gaussian and Lorentzian peak shapes. Beforehand, $\mathrm{X}$-ray satellite from $\mathrm{K}_{\mathrm{a} 3}, \mathrm{~K}_{\mathrm{a} 4}$ and $K_{\beta}$ radiation were subtracted. ${ }^{[62]}$ Background fitting was performed by using a combination of Shirley background and polynomial background, which was described by constant, linear and quadratic parameter.

\section{Electrochemical measurements}

Cyclic voltammetry (CV) and chronoamperometric electrochemical etching was conducted with an Autolab potentiostat PGSTAT128N (Metrohm) and the corresponding software Nova 2.0, respectively. Measurements were performed in a glass vial or in case of alkaline electrolytes in an electrochemical cell made of polypropylene to avoid glass corrosion. Self-made CMEs were used as working electrodes. A $\mathrm{Hg} / \mathrm{Hg}_{2} \mathrm{SO}_{4}$-electrode or a $\mathrm{Hg} / \mathrm{HgO}$-electrode (for alkaline electrolytes) was applied as reference electrodes. For comparison of experiments, all potentials are referred to the potential of a reversible hydrogen electrode $(\mathrm{RHE})\left(E_{\mathrm{RHE}} \approx E_{\mathrm{SHE}}+0.059 \mathrm{pH}\right)$. A coiled platinum or a tungsten wire served as auxiliary electrode. All experiments except ORR studies were conducted in $\mathrm{N}_{2}$-purged solutions.

\section{Cavity-microelectrodes}

CMEs were prepared by a procedure described elsewhere. ${ }^{[43,44]}$ First, gold-microelectrodes are prepared by sealing a gold wire with a nominal radius $r$ of $25 \mu \mathrm{m}$ inside a borosilicate glass capillary. The electrode was polished with several grades of abrasive paper down to $0.01 \mu \mathrm{m}$ grain size and connected to a copper wire with silver-epoxy glue (EPO-TEK®, John P. Kummer $\mathrm{GmbH}$ ). The resulting microelectrodes were cleaned electrochemically by cycling in $0.5 \mathrm{~mol} \mathrm{~L}^{-1}$ sulphuric acid solution and CMEs were prepared by electrochemical etching in $1 \mathrm{~mol} \mathrm{~L}^{-1} \mathrm{HCl}$ aqueous solution at $1.45 \mathrm{~V}$ for 60 to $180 \mathrm{~s}$. This procedure resulted in cavity depths between 10 and $30 \mu \mathrm{m}$. The average cavity depth was determined relative to the glass surface by confocal laser scanning microscopy (Leica TCS SP2, Leica Microsystems Heidelberg GmbH, Germany) equipped with a HC PL Fluotar 50x/0.8 dry lens. A series of scans in z-direction in reflection mode at a wavelength of $633 \mathrm{~nm}$ and subsequent transformation into topographic images was performed. Qualitative analysis of empty CME was performed by scanning electron microscopy (SEM) with a Helios Nanolab 600i system (FEI Company, Eindhoven, The Netherlands) with a detector for energy dispersive analysis of $\mathrm{x}$-rays at $10 \mathrm{kV}$ accelerating voltage. CMEs were filled with the respective catalyst by dipping into a small portion of the powdered sample. Complete filling was controlled with an optical microscope. CMEs can be reused several times by emptying the cavity volume in an ultrasonic bath. Hereafter, CMEs are denoted following the nomenclature

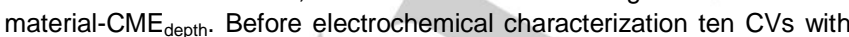
a scan rate of $50 \mathrm{mV} \mathrm{s}^{-1}$ in $0.1 \mathrm{~mol} \mathrm{~L}^{-1} \mathrm{KOH}$ solution were recorded to achieve a stabile current signal.

\section{Assessment of the surface area of metal oxide}

$\mathrm{CV}$ in $0.1 \mathrm{~mol} \mathrm{~L}^{-1} \mathrm{KOH}$ solution was performed for determining the double layer capacitance and was measured in a small potential window $( \pm 50 \mathrm{mV}$ ) with respect to OCP (determined before) with scan rates $v$ of $0.005,0.01,0.025,0.05,0.1,0.2,0.3,0.5$ and $0.8 \mathrm{~V} \mathrm{~s}^{-1}$. The vertex potentials were hold for $10 \mathrm{~s}$. Afterwards, cathodic and anodic charging currents $I_{c}$ at open circuit potential were plotted against $v$, and the double layer capacitance $C_{D L}$ was calculated from linear regression. The surface area of metal oxides $A_{\mathrm{MO}}$ was determined by dividing the double layer capacitance by the specific capacitance $C_{\mathrm{s}}=40 \mu \mathrm{F} \mathrm{cm}^{-2}$ of metal oxide surfaces in alkaline electrolytes. ${ }^{[23,24]}$

\section{Oxygen reduction reaction}

$\mathrm{CV}$ of ORR was conducted in $\mathrm{O}_{2}$-saturated $0.1 \mathrm{~mol} \mathrm{~L}^{-1} \mathrm{KOH}$ solution at room temperature. The potential was scanned from $1.066 \mathrm{~V}$ to $0.366 \mathrm{~V}$ with a scan rate of $0.001 \mathrm{~V} \mathrm{~s}^{-1}$ for metal oxides and $0.005 \mathrm{~V} \mathrm{~s}^{-1}$ for $\mathrm{Pt} / \mathrm{C}$ catalyst, respectively. The third cathodic scan of three consecutive cycles was used for data evaluation. Due to the overall small currents and the small geometric surface area, no correction for ohmic and capacitive effects was necessary for the CME setup.

\section{Acknowledgements}

The authors are grateful to Lisa Vogelsang (DLR Oldenburg) for support in ICP-MS measurements. We thank Dr. Carsten Dosche (University of Oldenburg) and Dr. Ronald Hesse (Unifit Scientific Software $\mathrm{GmbH}$ ) for advice in XPS peak fitting and discussion of results. The XPS instrumentation is funded by the German Research Foundation (DFG) through grant INST 184/144-1 FUGG. This work was partly supported by the MAXNET Energy consortium and IMPRS-RECHARGE of Max Planck Society.

Keywords: Fuel Cells - Mesoporous materials • Non-platinum group metal (non-PGM) $\bullet$ Powder microelectrode $\cdot$ Spinel phase

[1] W. T. Hong, M. Risch, K. A. Stoerzinger, A. Grimaud, J. Suntivich, Y. Shao-Horn, Energy Environ. Sci. 2015, 8, 1404-1427.

[2] I. Katsounaros, S. Cherevko, A. R. Zeradjanin, K. J. J. Mayrhofer Angew. Chem. Int. Ed. 2014, 53, 102-121.

[3] S. Gottesfeld, D. R. Dekel, M. Page, C. Bae, Y. Yan, P. Zelenay, Y. S. Kim, J. Power Sources 2018, 375, 170-184

[4] J. Suntivich, H. A. Gasteiger, N. Yabuuchi, H. Nakanishi, J. B. Goodenough, Y. Shao-Horn, Nature Chemistry 2011, 3, 546-550.

[5] V. Celorrio, L. Calvillo, E. Dann, G. Granozzi, A. Aguadero, D. Kramer A. E. Russell, D. J. Fermin, Catal. Sci. Technol. 2016, 6, 7231-7238.

[6] E. Fabbri, M. Nachtegaal, X. Cheng, T. J. Schmidt, Adv. Energy Mater 2015, 5, 1402033

[7] C. Wei, Z. Feng, G. G. Scherer, J. Barber, Y. Shao-Horn, Z. J. Xu, Adv Mater. 2017, 29, 1606800.

[8] T. Sönmez, S. J. Thompson, S. W. T. Price, D. Pletcher, A. E. Russell, J. Electrochem. Soc. 2016, 163, H884-H890.

[9] Q. Zhao, Z. Yan, C. Chen, J. Chen, Chem. Rev. 2017, 117, 10121 10211.

[10] Y. Liang, Y. Li, H. Wang, J. Zhou, J. Wang, T. Regier, H. Dai, Nat Mater. 2011, 10, 780-786.

[11] P. W. Menezes, A. Indra, D. González-Flores, N. R. Sahraie, I. Zaharieva, M. Schwarze, P. Strasser, H. Dau, M. Driess, ACS Catal. 2015, 5, 2017-2027.

[12] A. Serov, N. I. Andersen, A. J. Roy, I. Matanovic, K. Artyushkova, P. Atanassov, J. Electrochem. Soc. 2015, 162, F449-F454.

[13] G. Wu, J. Wang, W. Ding, Y. Nie, L. Li, X. Qi, S. Chen, Z. Wei, Angew. Chem. Int. Ed. 2016, 55, 1340-1344.

[14] U. A. Paulus, T. J. Schmidt, H. A. Gasteiger, R. J. Behm, J. Electroanal Chem. 2001, 495, 134-145.

[15] K. J. J. Mayrhofer, D. Strmcnik, B. B. Blizanac, V. Stamenkovic, M. Arenz, N. M. Markovic, Electrochim. Acta 2008, 53, 3181-3188. 
[16] J. Suntivich, H. A. Gasteiger, N. Yabuuchi, S.-H. Yang, J. Electrochem Soc. 2010, 157, B1263-B1268.

[17] E. Guilminot, A. Corcella, M. Chatenet, F. Maillard, J. Electroanal. Chem. 2007, 599, 111-120.

[18] A. J. Bard, L. R. Faulkner, Electrochemical Methods: Fundamentals and Applications, 2 ed., John Wiley \& Sons, 2001

[19] C. Cachet-Vivier, M. Keddam, V. Vivier, L. T. Yu, J. Electroanal. Chem 2013, 688, 12-19.

[20] D. Chen, Q. Tao, L. W. Liao, S. X. Liu, Y. X. Chen, S. Ye, Electrocatalysis 2011.

[21] S. Trasatti, O. A. Petrii, Pure Appl. Chem. 1991, 63, 711-734.

[22] P. J. Ferreira, G. J. Ia O', Y. Shao-Horn, D. Morgan, R. Makharia, S. Kocha, H. A. Gasteiger, J. Electrochem. Soc. 2005, 152, A2256-A2271.

[23] C. C. L. McCrory, S. Jung, J. C. Peters, T. F. Jaramillo, J. Am. Chem. Soc. 2013, 135, 16977-16987.

[24] S. Jung, C. C. L. McCrory, I. M. Ferrer, J. C. Peters, T. F. Jaramillo, J. Mater. Chem. A 2016, 4, 3068-3076.

[25] M. Yu, C. K. Chan, H. Tüysüz, ChemSusChem 2018, 11, 605-611.

[26] M. De Koninck, S.-C. Poirier, B. Marsan, J. Electrochem. Soc. 2007, 154, A381-A388.

[27] S. Ardizzone, G. Fregonara, S. Trasatti, Electrochim. Acta 1990, 35, 263-267.

[28] G. Spinolo, S. Ardizzone, S. Trasatti, J. Electroanal. Chem. 1997, 423, 49-57.

[29] A. Minguzzi, F.-R. F. Fan, A. Vertova, S. Rondinini, A. J. Bard, Chemical Science 2012, 3, 217-229.

[30] V. Celorrio, E. Dann, L. Calvillo, D. J. Morgan, S. R. Hall, D. J. Fermin ChemElectroChem 2016, 3, 283-291.

[31] H. Tüysüz, C. W. Lehmann, H. Bongard, B. Tesche, R. Schmidt, F. Schüth, J. Am. Chem. Soc. 2008, 130, 11510-11517.

[32] X. Deng, W. N. Schmidt, H. Tüysüz, Chem. Mater. 2014, 26, 6127-6134.

[33] T. Grewe, X. Deng, H. Tüysüz, Chem. Mater. 2014, 26, 3162-3168.

[34] T. Grewe, X. Deng, C. Weidenthaler, F. Schüth, H. Tüysüz, Chem. Mater. 2013, 25, 4926-4935.

[35] Y. Gorlin, T. F. Jaramillo, J. Am. Chem. Soc. 2010, 132, 13612-13614.

[36] X. Wu, K. Scott, J. Power Sources 2012, 206, 14-19.

[37] M. De Koninck, S.-C. Poirier, B. Marsan, J. Electrochem. Soc. 2006, 153, A2103-A2110.

[38] K. Shinozaki, Y. Morimoto, B. S. Pivovar, S. S. Kocha, J. Power Sources 2016, 325, 745-751.

[39] H. Tüysüz, Y. J. Hwang, S. B. Khan, A. M. Asiri, P. Yang, Nano Res. 2013, 6, 47-54.

[40] I. Abidat, N. Bouchenafa-Saib, A. Habrioux, C. Comminges, C. Canaff, J. Rousseau, T. W. Napporn, D. Dambournet, O. Borkiewicz, K. B. Kokoh, J. Mater. Chem. A 2015, 3, 17433-17444.

[41] X. Deng, S. Öztürk, C. Weidenthaler, H. Tüysüz, ACS Appl. Mater. Interfaces 2017, 9, 21225-21233.

[42] Y. J. Sa, K. Kwon, J. Y. Cheon, F. Kleitz, S. H. Joo, J. Mater. Chem. A 2013, 1, 9992-10001.

[43] M. L. Tremblay, M. H. Martin, C. Lebouin, A. Lasia, D. Guay, Electrochim. Acta 2010, 55, 6283-6291.

[44] M. Haensch, J. Behnken, L. Balboa, A. Dyck, G. Wittstock, Phys. Chem. Chem. Phys. 2017, 19, 22915-22925.

[45] C. Punckt, M. A. Pope, I. A. Aksay, J. Phys. Chem. C 2013, 117, 16076-16086.

[46] C. Locatelli, A. Minguzzi, A. Vertova, P. Cava, S. Rondinini, Anal. Chem 2011, 83, 2819-2823.

[47] V. Vivier, C. Cachet - Vivier, S. Mezaille, B. L. Wu, C. S. Cha, J. Y. Nedelec, M. Fedoroff, D. Michel, L. T. Yu, J. Electrochem. Soc. 2000 147, 4252-4262.

[48] R. Boggio, A. Carugati, S. Trasatti, J. Appl. Electrochem. 1987, 17, 828-840.

[49] D. Pletcher, X. Li, S. W. T. Price, A. E. Russell, T. Sönmez, S. J. Thompson, Electrochim. Acta 2016, 188, 286-293.

[50] F. Gloaguen, R. Durand, J. Appl. Electrochem. 1997, 27, 1029-1035.
[51] F. Gloaguen, F. Andolfatto, R. Durand, P. Ozil, J. Appl. Electrochem. 1994, 24, 863-869

[52] F. Gloaguen, P. Convert, S. Gamburzev, O. A. Velev, S. Srinivasan, Electrochim. Acta 1998, 43, 3767-3772.

[53] L. Genies, Y. Bultel, R. Faure, R. Durand, Electrochim. Acta 2003, 48 3879-3890.

[54] M. Mamlouk, S. M. S. Kumar, P. Gouerec, K. Scott, J. Power Sources 2011, 196, 7594-7600.

[55] J. K. Norskov, J. Rossmeisl, A. Logadottir, L. Lindqvist, J. R. Kitchin, T. Bligaard, H. Jónsson, J. Phys. Chem. B 2004, 108, 17886-17892.

[56] A. M. Bond, D. Luscombe, K. B. Oldham, C. G. Zoski, J. Electroanal Chem. Interfacial Electrochem. 1988, 249, 1-14

[57] R. Gao, J. Zhu, X. Xiao, Z. Hu, J. Liu, X. Liu, J. Phys. Chem. C 2015, $119,4516-4523$.

[58] J. Xu, P. Gao, T. S. Zhao, Energy Environ. Sci. 2012, 5, 5333-5339.

[59] X. Wu, K. Scott, J. Mater. Chem. 2011, 21, 12344-12351.

[60] Y. Li, P. Hasin, Y. Wu, Adv. Mater. 2010, 22, 1926-1929.

[61] X. Deng, K. Chen, H. Tüysüz, Chem. Mater. 2017, 29, 40-52.

[62] S. Hofmann, Auger- and X-Ray Photoelectron Spectroscopy in Materials Science - A User-Oriented Guide, Springer, Berlin Heidelberg, 2013. 


\section{Entry for the Table of Contents}

\section{ARTICLE}

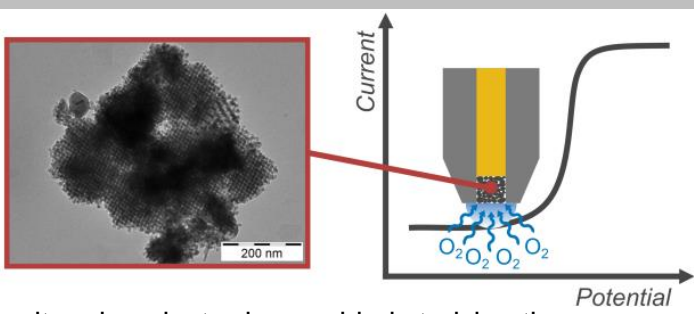

Application of cavity-microelectrodes enabled studying the oxygen reduction reaction of cobalt-based metal oxides without the influence of additives. The surface area was assessed by measuring the double layer capacitance. Thus, evaluation of specific activity values for the ORR was achievable.
Julian Behnken, * Mingquan Yu, Xiaohui Deng, Harun Tüysüz, Corinna Harms, Alexander Dyck and Gunther Wittstock*

$$
\text { Page No. - Page No. }
$$

Oxygen Reduction Reaction Activity of Mesostructured Cobalt-based Metal Oxides Studied with CavityMicroelectrode Technique 


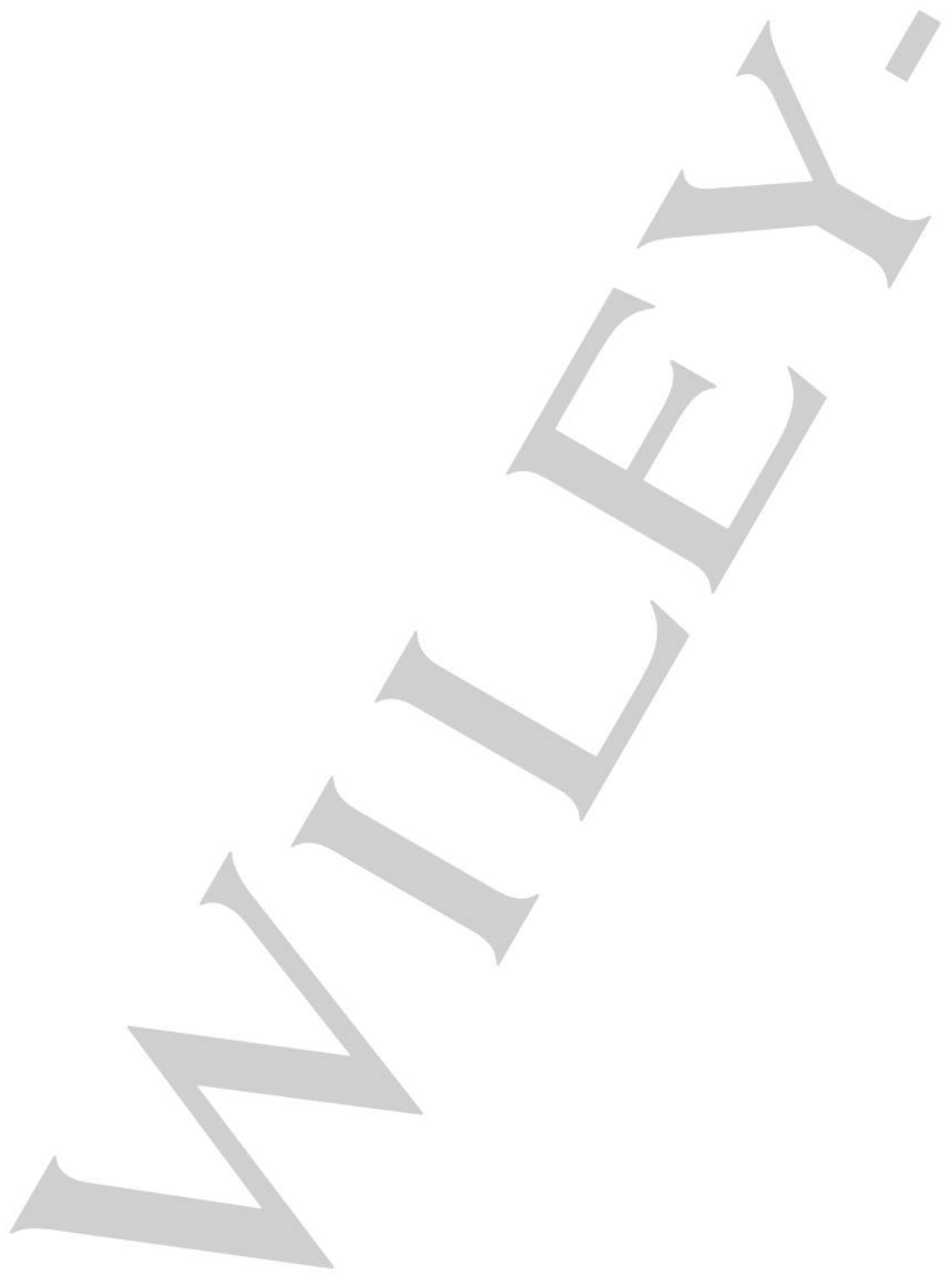

